\title{
Profitability and cost shifting in government procurement contracts ${ }^{*}$
}

\author{
Hui Chen \\ University of Zürich \\ Katherine Gunny ${ }^{\dagger}$ \\ University of Colorado, Boulder
}

This draft: August 2014

\begin{abstract}
We examine whether contractors with cost plus contracts earn a higher profit, and whether the higher profit is associated with cost shifting behavior, using a unique set of data of federal procurement contracts between the years 2005 and 2010. Prior research often examines government contractor profitability without differentiating the contract types, which is a key determinant to the contractor's ability to cost-shift. We identify firms that are awarded with cost plus contracts in some years and without in other years. We find their profitability significantly increases during the years that cost plus contracts are awarded. We also find that these firms exhibit greater discretionary expenditures during the years with cost plus contracts, relative to the years without, which is consistent with cost shifting behavior. However, effective monitoring through the Cost Accounting Standards helps mitigate such behavior.
\end{abstract}

\footnotetext{
* The authors’ emails are hui.chen@business.uzh.ch and katherine.gunny@ colorado.edu. We thank Yonca Ertimur, Bjorn Jorgensen, Steve Rock, and workshop participants at University of Colorado at Boulder for helpful comments.

$\dagger$ Corresponding author.
} 


\section{Introduction}

The U.S. government spends an enormous amount of money on public procurement. For example, the U.S. federal government reported $\$ 391.3$ billion and $\$ 540.1$ billion on procurement in the year 2005 and2010, respectively. ${ }^{1}$ Partially due to its significance in amount, popular opinions toward government procurement have been controversial. It is often believed that government contractors earn too high a profit at the tax payers' expense, and the government does not provide enough monitoring to discipline the contractors. To respond to the growing dissatisfaction against federal contractors, President Obama has proposed and implemented a series of new initiatives to further tighten the requirements for federal contractors. One of these new measures is to move away from cost plus contracts while adopting more fixed price contracts (Michaels and Cole, 2009).

Fixed price and cost plus are the two most common types of procurement contracts offered by the U.S. federal government to procurement contractors. ${ }^{2}$ For a fixed price contract, a contractor provides a product or service to the government at a fixed price that is previously determined through the negotiation or bidding process. For a cost plus contract, the contract price is equal to a contractor's cost to produce the product or service plus a profit margin. That is, with a cost plus contract, the government reimburses the contractor for its declared costs to fulfill the contract, and pays it an additional fee or profit rate according to the negotiation. Therefore, if offered a cost plus contract, a contractor has an incentive to inflate its reported costs to earn a higher profit. Specifically, the contractor could use accounting discretions to shift costs from

\footnotetext{
${ }^{1}$ See: http://www.usaspending.gov/

${ }^{2}$ In practice, there can be hybrids of both types of contracts. For example, Rogerson (1992) describes four common types of contracts employed by the U.S. Department of Defense: (1) pure fixed price (2) pure cost reimbursement (3) incentive fixed price (i.e realized costs are reimbursed up to a pre-specified threshold level) (4) incentive cost reimbursement (i.e. incentive fixed price contracts revert to pure cost reimbursement at a pre-specified threshold cost level). For our analysis, we refer to any contracts with revenue that is sensitive to the seller's cost as cost plus. In sensitivity analysis we ensure our results are robust to this empirical choice.
} 
other segments of its business to the government business. Cost plus contracts are therefore often considered as "abuse-prone."

In this paper, we use a unique set of data to examine whether contractors with cost plus contracts earn a higher profit, and whether the higher profit is associated with cost shifting behavior. To control for other confounding exogenous factors, we identify firms that are awarded with cost plus contracts in some years and without in other years. We find their profitability significantly increases during the years that cost plus contracts are awarded. We also find that these firms exhibit greater discretionary expenditures during the years with cost plus contracts, relative to the years without, consistent with cost shifting behavior. However, effective monitoring through the Cost Accounting Standards seems to help mitigate such behavior.

A vast theoretical literature explores the issues of optimal contracts and information problems in procurement setting (Laffont and Tirole 1986; McAfee and McMillan 1986; Rogerson 1992; Rogerson 1994; etc.). Since the government cannot costlessly observe the true cost incurred by a contractor, the contractor with a cost plus contract can manipulate the reported cost through cost inflation or cost shifting. Specifically, Rogerson (1992) demonstrates that a government contractor could over-allocate overhead cost into government contracts, while under-allocate overhead cost into commercial contracts, to strategically shift cost from commercial business to government business. Further, with the presence of such informational asymmetry, a first best solution can never be achieved. In contrast, fixed price contracts do not lead to such distortion of incentives as the contractor fully captures any profit/loss earned under the fixed price, regardless of its real cost or reported cost.

Empirical evidence on government contractors' cost-shifting behavior has been scant, mainly due to the lack of data. Until 2004, information about which government contractors 
received a cost plus contract was not publicly disclosed. A few empirical papers examine cost shifting and profitability among government contractors, but without differentiating the types of contracts. Thomas and Tung (1992) find evidence that department of defense contractors shift pension costs to the government. Lichtenberg (1992) finds government contractors earned excess profits on government contracts in the 1980s and suggests cost shifting as the reason. However, McGown and Vendrzyk (2002) hypothesize that a government contractor can only shift costs in a business segment with both government and commercial contracts. They fail to find significant differences in profitability between such business segments and their counterparts with only government or only commercial contracts. Therefore, they conclude that government contractors do not engage in cost shifting.

Prior research has also examined cost shifting in other settings. For example, Eldenburg and Soderstrom (1996) find that hospitals are engaged in cost shifting among payors using data from hospitals in the state of Washington. The cost shifting practice they focus on involves the hospital managers purposefully biasing budgeted information. Eldenburg and Kallapur (1997) examine the hospitals' response to a Medicare policy change in 1983. They find that the hospitals maximize their revenues by changing their patient mix and overhead. Eldenburg and Krishnan (2006) provide a comprehensive review on cost and incentive issues in the healthcare industry.

In this paper, we examine whether government contractors with cost plus contracts earn an unusually high profit; and if so, whether the high profitability is associated with cost shifting facilitated by accounting discretions. To address our research questions, we construct a database of 4.9 million federal procurement contracts (5,745 firm-years; 1,137 firms) between 2005 and 
2010 from the Federal Procurement Data System website. ${ }^{3}$ For our main test, we identify U.S. publicly-traded government contractors that have been awarded with a cost plus contract in at least one year, and with only fixed price contracts in at least another one year during our sample period. The final sample consists of 258 firms, or 1,505 firm-years. This sample enables us to use the firm as its own control and mitigates concerns that firm characteristics drives differences in cost shifting and profitability. We find that our sample firms have greater discretionary expenditures as well as higher profitability during the years with cost plus contracts, relative to other years without cost plus contracts. This is consistent with the conventional wisdom that government contractors that are awarded with cost plus contracts engage in cost shifting to obtain higher profits.

In addition, we examine the effect of government monitoring through two cross-sectional tests. We identify contracts that are required to be compliant with the Cost Accounting Standards (CAS). When contracts (both fixed and cost plus) are subject to CAS coverage, the firm is required to provide a detailed disclosure about the accounting policies used to determine CAS related costs, thus facing increased monitoring efforts by the government to prevent cost shifting. We predict the association between cost plus contracts and profitability to decrease as the percentage of revenue subject to CAS increases. Our results are consistent with our predictions.

We conduct several sensitivity tests to rule out alternative explanations. First, we employ different samples to ensure our results are not sensitive to sample selection. For our main analysis, the firm serves as its own control, by using 1,505 firm-years (258 firms) with at least one year with a cost contract and one year without a cost contract over the sample period. Our results are robust to two alternative subsamples: (1) all contractors (5,745 firm-years, 1,137

\footnotetext{
${ }^{3}$ https://www.fpds.gov/fpdsng_cms/index.php/en/
} 
firms) and (2) all contractors with at least one cost contract (2,201 firm-years, 383 firms).

Second, for our main analyses, we refer to any contracts with revenue that is sensitive to the seller's cost as cost plus. However, in practice contracts are often hybrids that fall in the spectrum between cost plus and fixed price. Our results are robust to using a sample which includes only pure fixed price and pure cost reimbursement.

Please note that our findings do not endorse the view that cost plus contracts should be reduced or even eliminated in government procurement. Different forms of contracts serve different purposes and different contracting environments. Prior research (citexxx) on optimal contract form demonstrates that factors such as project-specific risk, market competition, contractor characteristics, and trust, are critical in determining the contract form. For example, when the nature of a project is long-term and highly uncertain, the government is more likely to adopt cost plus contract to share risk. Same is true is when the contractor firm has low risk tolerance because it is young in age, small in size, and/or highly-leveraged. Fixed price contracts often imply higher risk for the contractor, thus applicable only when the project outcome is certain or when the contractor has high risk tolerance. Further, the informational rent earned by government contractors is inevitable when there is informational asymmetry. The government can never obtain the contractors' true cost information because frequent audits are costly. The government must trade off the potential gains recovered from these audits and the monitoring cost.

Our paper makes several contributions to the literature. First, we are the first paper that examines government procurement using contract-level data, which provides a cleaner setting than prior studies. McGowan and Vendrzyk (2002) do not differentiate contract types and fail to find evidence of higher profitability for defense contractors. This result could be due to the fact 
that, for our sample, only $4 \%$ of contracts are cost plus and only $37 \%$ of government contractors have cost plus contracts. Not differentiating the contract types could bias against finding differential profitability because only cost plus contracts provide an incentive to shift cost and increase profits. Further, McGowan and Vendrzyk (2002) examine firms' government segment profitability relative to commercial segment profitability. Before 1998 and the implementation of Statement of Financial Accounting Standards 131, firms had more discretion in their segment reporting (Berger and Hann 2007) and could have had proprietary reasons to withhold reporting profitable segments. Thus, examining segment profitability also biases against finding differential profitability.

Second, we examine research and development (R\&D) expense and selling, general, and administrative (SG\&A) expense as the expenditures used by contractors to shift costs. Thomas and Tung (1992) examine defense contractors and whether they shift pension costs across contracts and time to the government. They find evidence of cost shifting using pension costs. One difficulty in interpreting their results is that cost plus contracts could provide an incentive to increase promised pension cost benefits. Thus, their observed cost increase might be due to increasing promised pension payments rather than cost shifting. In contrast, R\&D and SG\&A are not susceptible to this criticism. Our results confirm that procurement contractors shift costs, consistent with Thomas and Tung (1992), and provides evidence on other types of expenditures used for cost shifting purposes besides pension costs.

Third, we provide evidence that cost shifting is one explanation for the relatively higher profitability of government contractors. Lichtenberg (1992) finds excess profits on government contracts in the 1980s and suggests cost shifting as the explanation. McGowan and Vendrzyk (2002) do not examine cost shifting directly and infer from their segment profitability 
comparisons that cost shifting is not a likely explanation for excess profitability. They suggest the result in Lichtenberg (1992) is likely due to other nonaccounting explanations. In contrast, we directly examine both cost shifting behavior and profitability. We find evidence that cost shifting is one explanation for relatively higher profitability.

Lastly, we are the first to provide evidence on the effectiveness of cost accounting standards. Our evidence suggests that cost accounting standards mitigate the positive association between cost plus contracts and profitability. When cost accounting standards apply to the contract, there is increased monitoring by the government and increased disclosure requirements about cost, which likely decrease the contractors ability to shift cost. Although our evidence sheds light on the benefits of cost accounting standards, we do not attempt to conclude on the tradeoff between the costs and benefits associated with these standards. The government must trade off the recovered gain from monitoring contractors with the cost of monitoring.

\section{Background and hypotheses development}

The contract terms under fixed price and cost plus contracts are different, which result in different incentives for the contractors. For a fixed price contract, the contractor provides a product or service to the government at a fixed price. For example, the department of homeland security contracts with Dell Inc. to buy laptop computers at a fixed price per unit. In most cases, no ex post renegotiation of the agreed upon price is permitted, therefore the government knows the final price before the project begins. Since the contract price is fixed, contract revenue is not sensitive to the seller's cost of production. The seller bears the risk associated with any cost overruns associated with the project.

With cost plus contracts the contract revenue is sensitive to the seller's cost. The contract revenue is equal to the seller's cost to produce the product or service plus a fixed fee or 
guaranteed profit margin. Thus the government does not know the final price before the project begins and bears the risk of any cost overruns. Generally, when the costs are difficult to estimate ex ante or when the product or service is hard to explicitly define ahead of time the government may have incentives to offer a cost plus contract. For example, an aerospace firm contracts with the National Aeronautics and Space Administration (NASA) to build a rocket propulsion unit. For the aerospace company to produce the unit, they need to make a transaction specific investment in technology and human capital specifically tied to producing the rocket propulsion unit because the product is highly specialized and only in demand by NASA. From the aerospace firms perspective engaging in this transaction under a fixed price contract is perhaps too risky given the required amount of investment and the inherent uncertainty and complexity of the project. To appropriately share risk and incentivize the aerospace firm to make the requisite amount of investment, NASA would likely have to offer a cost plus contract and bear the risk of any cost overruns.

Under cost plus contracts, contractors have incentives to shift costs to the government whereas under fixed price contracts they generally do not. Obviously, if incurred costs were observable, there could be no cost shifting, the government would reimburse the contractor for expenditures incurred only for the contracted project. However, when there is information asymmetry between the contractor and the government, the true cost information is difficult to verify. Popular opinion often holds that cost plus contracts enable the contractors to cost shift and help the contractors earn a higher profitability. Since the contractor's revenue increases in the cost reimbursed, the contractor's profit will be higher when it shifts other cost to the government contracts. Specifically, if a firm receives cost plus contracts in some years and fixed 
price contracts in others, its profitability could vary across years due to the differential availability of cost shifting based on contract type. This leads to our first hypothesis:

\section{H1: Government procurement contractors' profitability is higher in years with a cost plus contract relative to years without cost plus contracts.}

Thomas and Tung (1992) point out that contractor firms can shift costs both intercontract and inter-time. With inter-contract shifting, firms shift cost from non-cost plus contracts (e.g., private sector or fixed price government contracts) to cost plus contracts within the same contract period. For example, a firm spends a total of $\$ 100$ million on $R \& D$ expenditures and reports $\$ 100$ million in $\mathrm{R} \& \mathrm{D}$ expense on the income statement. Out of \$100 million, \$20 million is incurred for the government contract and $\$ 80$ million was for the rest of the commercial business. However, the contractor firm could shift $\$ 5$ million of $R \& D$ expenses from commercial business to the government project. Therefore, the government must reimburse the firm $\$ 25$ million for its R\&D expenses, while the firm's commercial section gets "subsidized" by $\$ 5$ million. Empirically, it is difficult to observe inter-contract cost shifting because in both cases the firm reports $\$ 100$ million in $R \& D$ expense on the income statement.

With inter-period shifting, firms shift costs into contract periods with a cost plus contract from periods without a cost plus contract. For example, a firm spends a total of $\$ 100$ million on R\&D expenditures. Let us again assume the contractor firm should incur $\$ 20$ million of $R \& D$ expenses on the government project. With inter-period cost shifting the firm could purposefully engage in more $R \& D$ activities than necessary to fulfill the government contract, and these research activities could benefit its commercial business in the future. If the incremental expense amounts to an additional $\$ 5$ million in $R \& D$ costs, the government ends up subsidizing the contractor's commercial business by overpaying $\$ 5$ million dollars. With inter-period cost 
shifting the firm reports $\$ 105$ million on the income statement for the year it has a cost plus contract with the government, instead of $\$ 100$ million if it does not. Therefore inter-period cost shifting can be detected empirically from the firm's financial statement information.

In this paper, we proxy for the government contractors' inter-period cost shifting using their discretionary expenditures. Our second hypothesis is therefore:

\section{H2: Government procurement contractors' discretionary expenditure is higher in years with a cost plus contract relative to years with only fixed price contracts.}

When there is information asymmetry between the contractor and the government, the contractor can include more expenditures in reimbursed cost than were actually incurred. Since the contractor's revenue is increasing in cost, more cost shifting will lead to a greater profitability. However, the government can increase its monitoring efforts to prevent cost shifting. With increased monitoring, the government can decrease the ability of contractors to shift costs. As such, we expect the association between cost contracts and profitability to decrease as monitoring by the government increases.

In terms of increased monitoring, some government contracts are subject to Cost Accounting Standards (CAS). Cost Accounting Standards are a set of 19 standards and rules for use in determining costs. ${ }^{4} \mathrm{~A}$ contract could be subject to full CAS coverage (i.e. required to follow all 19 standards), modified CAS coverage (required to follow only four standards: CAS $\# 401$, \#402, \#405, and \#406) ${ }^{5}$, or be exempt from coverage. There are many reasons a contract could be exempt from CAS, including that a contract is less than $\$ 7.5$ million (and the firm does

\footnotetext{
${ }^{4}$ For example, Thomas and Tung (1992) describe the CAS pension rules (\#412 and \#413) as similar to tax rules and Generally Accepted Accounting Principles (GAAP) but more strict than Employee Retirement Income Security Act (ERISA) rules.

${ }^{5}$ CAS \#401 "Consistency in Estimating, Accumulating and Reporting Costs"; CAS\#402 "Consistency in Allocating Costs Incurred for the Same Purpose"; CAS \#405 “Accounting for Unallowable Costs; CAS \#406 "Cost Accounting Period".
} 
not have other contracts over 7.5 million), a contract is for commercial items, a contract has “adequate price competition", etc. When contracts are subject to full CAS coverage, the firm is required to provide a CAS Disclosure Statement, which describes in detail the accounting policies used to determine CAS related costs.

CAS standards can apply for both cost plus contracts and fixed price contracts. For fixed price contracts the information subject to CAS could be used in determining the contract price (i.e. the government uses the information to set the fixed price). For cost plus contracts the information subject to CAS could be used in determining the fixed fee, profit margin, or reimbursed costs. To the extent, contracts subject to CAS indicate increased monitoring efforts by the government to prevent cost shifting, we expect the association between cost contracts and profitability to decrease as monitoring by the government increases. This leads to our third hypothesis:

\section{H3: Government contractors with cost plus contracts are relatively less profitable when cost accounting standards apply.}

\section{Research Design}

3.1. Measure of discretionary expenditure Discretionary expenditures are defined as the sum of R\&D, advertising, and SG\&A expenditures. We estimate the following model based on the entire Compustat sample with data available to estimate the models following Roychowdhury (2006). We estimate the normal level of discretionary expenditures as follows:

$\operatorname{DisExp}_{t} /$ Assets $_{t-1}=\mu_{0}+\mu_{1}\left(1 /\right.$ Assets $\left._{t-1}\right)+\mu_{2}\left(S_{t-1} /\right.$ Assets $\left._{t-1}\right)+\varepsilon_{t}$

where,

$\operatorname{DisEx}_{t}=$ research and development expense plus advertising and selling, general and administrative expense

Assets $_{t-1}=$ total assets

$S_{t} \quad=$ sales 
Model (1) is estimated cross-sectionally for each industry-year with at least 15 observations. Continuous variables are winsorized at the $1 \%$ and $99 \%$ level to reduce the influence of outliers. For each firm-year, abnormal discretionary expenditure (Abnormal DisExp) is the residual from the corresponding industry-year regression. As an alternative proxy for abnormally high discretionary expenditures, we create an indicator variable equal to one if the residual from model (1) is in the highest quintile and zero otherwise (Abnormal DisExp_Q10) for a given year.

\subsection{Hypothesis testing}

To test our first hypothesis (H1), we adopt the following regression model used in Core et al. (1999):

$R O A=\beta_{0}+\beta_{1}$ Cost contract $+\beta_{2}$ Lagged ROA $+\beta_{3}$ StdROA $+\beta_{4}$ Log sales

where, $+\beta_{4} L$ Log procurement sales $+\varepsilon_{t}$

StdROA = standard deviation of ROA during the prior three years including year $\mathrm{t}$

Log sales $\quad=$ the natural logarithm of sales in millions

Log procurement sales $=$ the natural logarithm of procurement contract sales in millions

We include year and industry (two-digit SIC) fixed effects. We include the standard deviation of ROA over the fiscal year (Std ROA) and the natural logarithm of annual net sales (LnSales). We augment the Core et al. (1999) regression model and include ROA to control for the time-series properties of performance. Of particular interest to us is the coefficient on Cost contract. If contracting firms have higher return-on-assets in years with cost plus contracts, we should observe a positive $\beta_{1}$.

To test our second hypothesis (H2), we estimate the following OLS regression model:

$$
\begin{aligned}
\text { Abnormal DisExp/Abnormal DisExp_Q10= } & \alpha_{0}+\alpha_{1} \text { Cost contract }+\alpha_{2} \text { Log assets } \\
& +\alpha_{3} \text { Market-to-book }+\alpha_{4} R O A+\varepsilon_{t}
\end{aligned}
$$


where,

$\begin{array}{ll}\text { Abnormal DisExp } & \text { the residual from model (1) } \\ \text { Abnormal DisExp_Q10 }= & \text { an indicator variable equal to one if the residual from model (1) is } \\ & \text { in the highest quintile, and zero otherwise } \\ = & \text { an indicator variable equal to } 1 \text { if the firm has at least one cost } \\ & \text { contract, and zero otherwise } \\ = & \text { natural logarithm of total assets in millions } \\ = & \text { the market value of equity divided by the book value } \\ = & \text { earnings before extraordinary items divided by total assets }\end{array}$
$\begin{array}{ll}\text { Log asset } \\ \text { Market-to-book }\end{array}$

In all regressions, continuous variables are winsorized at the $1 \%$ and $99 \%$ level to reduce the influence of outliers and the standard errors are corrected to control for clustering across firm and year (Gow et al. 2010; Petersen 2009). The control variables are from Gunny (2010). Firm size, Log assets, controls for any size effects and the market-to-book ratio controls for growth opportunities. Return on assets, $R O A$, is included to address concerns that abnormal discretionary expenditures are correlated with performance. Of particular interest to us is the coefficient on Cost contract, $\alpha_{1}$. If contracting firms have higher discretionary expenditures in years with cost plus procurement contracts, we should observe a positive $\alpha_{1}$. A positive coefficient would be consistent with inter-period cost shifting and the results in Thomas and Tung (1992).

To test our third hypothesis (H3), we augment model (3) as follows: $\begin{aligned} \text { ROA }= & \gamma_{0}+\gamma_{1} \text { Cost contract } t_{t}+\gamma_{2} \% \text { CAS }_{t}+\gamma_{3} \% \text { CAS }^{*} \text { Cost contract }_{t}+\gamma_{4} \text { Lagged ROA } \\ & +\gamma_{5} \text { StdROA }+\gamma_{6} \text { Log sales }+\gamma_{7} \text { Log procurement sales }+\varepsilon_{t}\end{aligned}$ where,

$\% C A S=$ percentage of procurement revenue subject to the cost accounting standards

Hypothesis three suggests that the positive association between whether the firm has a cost plus contract and performance will be constrained as the government's monitoring effort increases. Our proxy for monitoring is the percent of contract revenue that is subject to the cost accounting standards $(\% C A S)$. When CAS standards apply, not only specific rules must be applied when determining costs but also the firm must produce CAS Disclosure Statement, 
which describes in detail the accounting policies used to determine CAS related costs. CAS standards can apply to fixed and cost plus contracts. For fixed contracts, this could help reduce information asymmetry when negotiating the price of the contract. For cost plus contracts, CAS could help by preventing cost shifting. Therefore, we expect a negative coefficient on the variable \%CAS. Of particular interest to us is the coefficient on the interaction between Cost contract and \%CAS. If firms with cost plus contracts are less profitable when a greater percentage of contract revenue is subject to CAS, we would expect a negative coefficient on the interaction term, $\gamma_{3}$.

\section{Sample and Descriptive Statistics}

\subsection{Sample selection}

Panel A of Table 1 describes the sample details. First, we retrieve data on all procurement contracts between 2004 and 2010 from the Federal Procurement Data System website. Next, we map the 21,657,724 contracts to firms available in Compustat and retain 6,098,655 contracts. Next, after requiring nonmissing control variables, we are left with 4,912,232 contracts, or 1,137 firms. Table 1 reveals that 209,278 (4.26\%) of contracts are cost plus and 379 (33.33\%) firms have at least one cost plus contract over the sample period. Panel B of Table 1 describes our three samples. Sample 1 consists of all procurement contractors in our sample including 5,745 firm-years (1,137 firms), of which 1,315 firm-years involve cost plus contracts and 4,439 firmyears do not. The next two samples exclude firms without cost plus contracts over the sample period. As discussed earlier, the government only offers cost plus contracts in certain situations, such as when the costs are difficult to estimate ex ante or when the product or service is hard to explicitly define ahead of time. As such, firms that receive cost contracts could be different than firms that do not receive cost contracts and this self-selection could bias our results. 
Sample 2 excludes firms without any cost contracts over the sample period and consists of 2,201 firm-years (383 firms), of which 1,315 firm-years have cost plus contracts and 886 do not. Sample 3 consists of firms with at least one year with a cost plus contract and one year without over the sample period. This sample consists of 1,505 firm-years (258 firms), of which 619 firm-years have cost plus contracts and 886 do not. ${ }^{6}$ Sample 3 allows each firm to serve as its own control and mitigate concerns that self-selection is driving our findings. Therefore, we use sample 3 in our main analysis and conduct sensitivity analysis using sample 1 and sample 2 .

\subsection{Descriptive statistics}

Panel A of Table 2 provides the descriptive statistics of contract revenue and frequency by contracting department. The first four columns describe all contracts and the last four columns provide analysis for cost plus contracts. The top three departments by contract revenue is the department of the army, navy, and air force. ${ }^{7}$ The general services administration and the department of veteran affairs have the greatest frequency of contracts.

Panel B of Table 2 provides the descriptive statistics of contract revenue and frequency by 3-digit North American Industry Classification System (NAICS). The government procurement database provides the NAICS code associated with each contract. The top three industries for all contracts by contract revenue are professional, scientific, and technical services (541), transportation equipment manufacturing (336), and computer and electronic product manufacturing (334). For cost plus contracts, professional, scientific, and technical services (541) is the largest and consists of $63 \%$ of all cost plus contract revenue. The next largest industry is transportation equipment manufacturing (336) which consists of $14 \%$ of cost plus

\footnotetext{
${ }^{6}$ The difference between sample 2 and sample 3 is that firms with a cost contract every year $(383-258=125$ firms $)$ are excluded.

${ }^{7}$ Because of data availability prior studies typically use a sample consisting of the Top 100 department of defense contracts (by revenue) who are publicly traded (e.g., Thomas and Tung 1992). The department of defense consists of the department of the army, navy, air force, and defense (non military).
} 
contract revenue. Cost plus contracts are typically awarded when the product or service is hard to explicitly define ahead of time. Consistent with this notion, industries with products and services that are difficult to specify (e.g., professional, scientific, and technical services) are awarded more frequently with cost plus contracts whereas industries with less complicated offerings (e.g., merchant wholesalers, nondurable goods) are not.

Table 3 presents descriptive statistics for a sample of 258 firms with at least one year with a cost plus contract and one year with only fixed price contracts. Panel A provides summary statistics for sample firm-years with at least one cost plus contract, and Panel B for firm-years with only fixed price contracts. Firm-years with cost contracts have significantly higher mean and median abnormal discretionary expenditures (Abnormal DisExp) than firm-years with only fixed price contracts. Also, both the mean and median return-on-assets $(R O A)$ are significantly higher for firm-years with at least one cost plus contract compared to firm-years with only fixed contracts. Overall, the univariate differences indicate that firm-years with at least one cost contract have and better financial performance and more discretionary expenditures, consistent with hypothesis one and two.

Between the samples with cost plus contracts and fixed price contracts, mean assets, market-to-book, standard deviation of ROA, sales, and procurement sales are not significantly different. These insignificant differences between the two samples indicate that our sample selection procedure that uses the firm as its own control mitigates concerns that firm characteristics drive the variation in our variables of interest (i.e. abnormal discretionary expenditures and return-on-assets). Lastly, \%CAS is significantly higher for the cost plus sample, which is expected since cost plus contracts are more likely to be subject to the cost accounting standards. 


\section{Results}

\subsection{Main results}

We report the results of estimating model (2) in Table 4. If cost plus contracts are associated with higher profitability relative to fixed contracts, we would expect the contractors to have better financial performance in years with cost plus contracts. Consistent with this expectation, we find a significantly positive relation between return-on-assets and whether the firm has a cost contract. Specifically, the coefficient on Cost contract, is $0.008(\mathrm{p}=0.03)$. This suggests that firm-years with cost plus contracts have higher profitability compared to firm-years with only fixed price contracts, consistent with our hypothesis one. In terms of economic significance, the marginal effect on Cost contract is $0.762 \%$. The marginal effect can be interpreted as the percentage increase in ROA during years with a cost contract. Mean assets for the sample is $\$ 3.33$ million, therefore, firm-years with cost contracts have earnings before extraordinary items that is $\$ 25.37$ million higher than firm years without cost contracts, holding all other variables at their mean.

We report the results of estimating model (3) in Table 5. We use two variables to proxy for abnormal discretionary expenditures. First, we estimate an ordinary least squares regression with the continuous variable, Abnormal DisExp, as the dependent variable. Second, we estimate a logistic regression with the dichotomous variable, Abnormal DisExp_Q10, as the dependent variable. The first column reveals a significant relation between abnormal discretionary expenditures and whether the firm has a cost contract. Specifically, the coefficient on Cost contract, is $0.128(\mathrm{p}=0.04)$. The second column reveals a significant relation between whether the firm is in the highest quintile of abnormal discretionary expenditures and whether the firm has a cost contract. The coefficient on Cost contract, is $0.411(\mathrm{p}=0.01)$. The analysis presented 
in Table 5 provides evidence consistent with hypothesis two, that procurement contractors shift costs across time to the government through cost pus contracts. Overall, our results provide evidence of cost shifting.

Taken together, the results in Table 4 and 5 suggest government procurement contractors shift costs to the government when they have cost plus contracts and this leads to greater profitability relative to firm-years with only fixed price contracts. Please note two important issues when interpreting these results. First, hypothesis two tests for inter-period cost shifting since it is easier to observe than inter-contract shifting. Even though we test exclusively for interperiod shifting, we believe both types of cost shifting could occur. Second, just because firms shift cost and have higher profits, we do not necessarily believe this is suboptimal from the governments perspective. The optimality of contract form is determined by many factors. Just because cost plus contracts may lead to distorted incentives, the appropriateness of fixed price contracts is still not warranted.

Hypothesis three suggests that the positive association between having a cost plus contract and the firm's financial performance is constrained as the government's monitoring increases. Our proxy for monitoring is the percent of contract revenue that is subject to cost accounting standards $(\% C A S)$. We test our third hypothesis (H3) and report the results of model (4) in Table 6. We continue to observe a positive relation between having a cost contract and the firm's return on assets. The coefficient on \%CAS is negative and significant, suggesting firm profitability decreases as the percentage of contract revenue subject to cost accounting standards increases. More importantly, we show that the relation between Cost contract and ROA varies with $\% C A S$ in the predicted manner. Specifically, the coefficient on the interaction between Cost contract and $\% C A S$ is significantly negative $\left(\gamma_{3}=-0.047, p=0.08\right)$. These results provide 
support for our third hypothesis (H3) and suggest that as the government's monitoring increases the association between having a cost plus contract and profitability decreases.

\subsection{Sensitivity Analysis}

For our main analysis, our sample consists of the 258 firms that have at least one year with a cost plus contract and one year without, over the sample period (see Panel B of Table 1, sample 3). For this sample, the firm serves as its own control. For a sensitivity test, we explore the robustness of our results to alternative control samples. We estimate model (2) and model (3) using two alternative samples: all contractors (see Panel B of Table 1, sample 1) and all contractors with at least once cost contract over the sample period (see Panel B of Table 1, sample 2).

We report the result of sensitivity analysis of estimating model (2) in Panel A of Table 9. For both alternative control samples, we continue to find a positive association between abnormal discretionary expenditures and the firm having a cost plus contract. Specifically, the coefficient on Cost contract for Sample 1, is $0.0659(\mathrm{p}=0.05)$ and the coefficient on Cost contract for Sample 2, is $0.0906(\mathrm{p}=0.04)$. Next, we report the result of sensitivity analysis of estimating model (3) in Panel B of Table 9. Again, we find a significantly positive relation between the firms' return on assets and the firms having a cost contract. Specifically, the coefficient on Cost contract for Sample 1, is $0.0045(\mathrm{p}=0.02)$ and coefficient on Cost contract for Sample 2, is $0.0070(\mathrm{p}=0.03)$. This provides evidence that our findings that firm-years with cost plus contracts have higher profitability compared to firm-years with only fixed price contracts is robust to alternative control samples.

We also use alternative categorization of contracts to re-run our tests. For the main analyses, we refer to any contracts with revenue that is sensitive to the seller's cost as cost plus. 
However, Rogerson (1992) describes four common types of contracts employed by the U.S. Department of Defense: (1) pure fixed price (2) pure cost reimbursement (3) incentive fixed price (i.e realized costs are reimbursed up to a pre-specified threshold level) (4) incentive cost reimbursement (i.e. incentive fixed price contracts revert to pure cost reimbursement at a prespecified threshold cost level). We estimate model (2) and model (3) on the sample including only (1) pure fixed price and (2) pure cost reimbursement and the results are robust.

\section{Conclusion}

In government procurement, cost plus contracts facilitate risk-sharing between the government and the contractors, especially when the product or service is difficult to define exante. It is however also believed that contractors abuse the flexibility provided by cost plus contracts and shift other costs to the government to earn a higher profit than deserved. In this paper, we use a unique dataset of the U.S. federal procurement contracts to examine whether contractors that are awarded with cost plus contracts earn a higher profit, and whether the higher profit is associated with cost shifting behavior. We find evidence consistent with cost plus contract being associated with higher profitability and greater discretionary expenditures, which are indicative of cost shifting. We also find that the government's monitoring through the Cost Accounting Standards helps mitigate this problem.

Our findings however do not indicate that cost plus contracts are inferior to fixed price contracts. Optimal contract form is determined by many factors, such as project-specific risk, market competition, contractor characteristics, and etc. Cost plus contracts are necessary when the uncertainty associated with the project is high. Further, once the cost plus contract is chosen, the contractors can earn an informational rent since the government cannot observe the true cost 
incurred by the contractor. More stringent monitoring is very costly and can be more expensive to the tax payers. 


\section{References}

Core, J., R. Holthausen, D. Larcker. 1999. Corporate governance, chief executive officer compensation, and firm performance. Journal of Financial Economics 51 (3): 371-406.

Eldenburg, L., and S. Kallapur. 1997. Changes in hospital service mix and cost allocations in response to changes in Medicare reimbursement schemes. Journal of Accounting and Economics, 23 (1) 31-51

Eldenburg, L., and R. Krishnan, 2006. Management Accounting and Control in Health Care: An Economics Perspective. Handbooks of Management Accounting Research. Volume 2, 85988.

Eldenburg, L., and N. Soderstrom. 1996. Accounting System Management by Hospitals Operating in a Changing Regulatory Environment. The Accounting Review, 71 (1) 2342.Gow, I. D., G. Ormazabal, and D. J. Taylor. 2010. Correcting for cross-sectional and time-series dependence in accounting research. The Accounting Review 85 (2): 483-512.

Gunny, K. A. 2010. The relation between earnings management using real activities manipulation and future performance: Evidence from meeting earnings benchmarks. Contemporary Accounting Research 18 (3): 868-891.

Laffont, J.J., and J. Tirole. 1993. A theory of incentives in procurement and regulation. Cambridge, MA: MIT Press.

Laffont, J.J., and J. Tirole. 1986. Using cost observation to regulate firms. Journal of Political Economy. 94 (3): 614-641.

Lichtenberg, F. 1992. A perspective on accounting for defense contracts. The Accounting Review 67 (4): 741-752.

McAfee, R. and P. McMillan. 1986. Bidding for contracts: a principal-agent analysis. RAND Journal of Economics 86 (17): 326-338.

McGowan, A. S. and V. P. Vendrzyk. 2002. The relation between cost shifting and segment profitability in defense-contracting industry. The Accounting Review 77 (4): 949-969.

Michaels, D. and A. Cole. 2009. Defense contractors resist fixed-price jobs. The Wall Street Journal.

Rogerson, W. 1992. Overhead allocation and incentives for cost minimization in defense procurement. The Accounting Review 67 (4): 671-690. 
Rogerson, W. 1994. Economic incentives and the defense procurement process. Journal of Economic Perspectives 8 (4): 65-90.

Roychowdhury, S. 2006. Earnings management through real activities manipulation. Journal of Accounting and Economics 42 (3): 335-370.

Thomas, J. and S. Tung. 1992. Cost manipulation incentives under cost reimbursement: Pension costs for defense contracts. The Accounting Review 67 (4): 691-711.

Petersen, M. A. 2009. Estimating standard errors in finance panel data sets: Comparing approaches. Review of Financial Studies 22 (1): 435-480. 
Table 1

Panel A: Sample selection

\begin{tabular}{|c|c|c|c|c|c|c|}
\hline Year & $\begin{array}{l}\text { All federal } \\
\text { procurement } \\
\text { contracts }\end{array}$ & $\begin{array}{l}\text { Contracts } \\
\text { mapped to } \\
\text { Compustat }\end{array}$ & $\begin{array}{c}\text { Contracts } \\
\text { with control } \\
\text { variables }\end{array}$ & Firms & $\begin{array}{l}\text { Cost plus } \\
\text { contracts }\end{array}$ & Firms \\
\hline 2005 & $2,849,310$ & 685,199 & 495,573 & 861 & 32,998 & 237 \\
\hline 2006 & $3,723,011$ & 926,604 & 753,137 & 916 & 35,445 & 247 \\
\hline 2007 & $4,008,419$ & $1,167,812$ & 972,510 & 937 & 33,079 & 264 \\
\hline 2008 & $4,391,358$ & $1,335,355$ & $1,114,443$ & 1,000 & 31,242 & 237 \\
\hline 2009 & $3,341,336$ & $1,019,336$ & 799,357 & 1,016 & 34,704 & 231 \\
\hline \multirow[t]{2}{*}{2010} & $3,344,290$ & 964,349 & 777,212 & 1,024 & 41,810 & 249 \\
\hline & $21,657,724$ & $6,098,655$ & $4,912,232$ & 1,137 & 209,278 & 379 \\
\hline
\end{tabular}

Panel B: Control samples

$\begin{array}{cccc} & & \begin{array}{c}\text { Firm-years } \\ \text { with at least } \\ \text { one cost }\end{array} & \begin{array}{c}\text { Firm-years } \\ \text { with no cost } \\ \text { contract (i.e. } \\ \text { contact }\end{array} \\ \text { Firm-years fixed) }\end{array}$

$\begin{array}{llll}\text { Sample } 1 & 5,745 & 1,137 & 1,315\end{array}$

*Includes all procurement contractors

$\begin{array}{lllll}\text { Sample } 2 & 2,201 & 383 & 1,315 & 886\end{array}$

*Includes procurement contractors with at least one cost contract over the sample period

$\begin{array}{llll}\text { Sample } 3 & 1,505 & 258 & 619\end{array}$

*Includes procurement contractors with at least one year with a cost plus contract and one year with only fixed contracts 
Table 2

Panel A: Contract revenue and frequency by contracting department

\begin{tabular}{|c|c|c|c|c|c|c|c|c|}
\hline \multirow[b]{2}{*}{ Department } & \multicolumn{4}{|c|}{ All contracts } & \multicolumn{4}{|c|}{ Cost plus contracts } \\
\hline & $\begin{array}{l}\text { Contract } \\
\text { revenue } \\
\text { (in millions) } \\
\end{array}$ & $\%$ & $\begin{array}{c}\text { \# of } \\
\text { contracts }\end{array}$ & $\%$ & $\begin{array}{c}\text { Contract } \\
\text { revenue } \\
\text { (in millions) } \\
\end{array}$ & $\%$ & $\begin{array}{c}\text { \# of } \\
\text { contracts }\end{array}$ & $\%$ \\
\hline Department of the army & 75,820 & $25 \%$ & 318,283 & $6 \%$ & 40,855 & $36 \%$ & 99,010 & $47 \%$ \\
\hline Department of the navy & 68,641 & $23 \%$ & 234,272 & $5 \%$ & 20,072 & $18 \%$ & 24,277 & $12 \%$ \\
\hline Department of the air force & 62,234 & $21 \%$ & 144,796 & $3 \%$ & 27,682 & $24 \%$ & 45,030 & $22 \%$ \\
\hline General services administration & 15,311 & $5 \%$ & $1,333,167$ & $27 \%$ & 1,118 & $1 \%$ & 1,047 & $1 \%$ \\
\hline Department of veteran affairs & 13,858 & $5 \%$ & $1,135,401$ & $23 \%$ & 45 & $0 \%$ & 183 & $0 \%$ \\
\hline National Aeronautics and space admin. & 10,725 & $4 \%$ & 27,088 & $1 \%$ & 7,587 & $7 \%$ & 8,471 & $4 \%$ \\
\hline Department of homeland security & 9,565 & $3 \%$ & 16,292 & $0 \%$ & 3,999 & $3 \%$ & 4,426 & $2 \%$ \\
\hline Department of defense (non military) & 8,046 & $3 \%$ & 46,589 & $1 \%$ & 2,154 & $2 \%$ & 1,979 & $1 \%$ \\
\hline Department of health and human services & 7,388 & $2 \%$ & 42,961 & $1 \%$ & 2,895 & $3 \%$ & 3,264 & $2 \%$ \\
\hline Department of the treasury & 4,934 & $2 \%$ & 24,265 & $0 \%$ & 1,799 & $2 \%$ & 2,463 & $1 \%$ \\
\hline Department of justice & 3,606 & $1 \%$ & 78,920 & $2 \%$ & 131 & $0 \%$ & 156 & $0 \%$ \\
\hline Department of the interior & 2,925 & $1 \%$ & 54,899 & $1 \%$ & 371 & $0 \%$ & 672 & $0 \%$ \\
\hline Department of state & 2,530 & $1 \%$ & 8,684 & $0 \%$ & 824 & $1 \%$ & 1,249 & $1 \%$ \\
\hline Department of transportation & 2,421 & $1 \%$ & 23,819 & $0 \%$ & 167 & $0 \%$ & 173 & $0 \%$ \\
\hline Department of energy & 2,382 & $1 \%$ & 7,209 & $0 \%$ & 1,647 & $1 \%$ & 1,475 & $1 \%$ \\
\hline Department of commerce & 1,978 & $1 \%$ & 18,546 & $0 \%$ & 665 & $1 \%$ & 1,467 & $1 \%$ \\
\hline Railroad retirement board & 1,368 & $0 \%$ & 4,455 & $0 \%$ & 1 & $0 \%$ & 7 & $0 \%$ \\
\hline Department of agriculture & 1,327 & $0 \%$ & 13,020 & $0 \%$ & 935 & $1 \%$ & 5,858 & $3 \%$ \\
\hline Agency for international development & 1,011 & $0 \%$ & 1,825 & $0 \%$ & 682 & $1 \%$ & 462 & $0 \%$ \\
\hline Department of the labor & 861 & $0 \%$ & 9,501 & $0 \%$ & 422 & $0 \%$ & 442 & $0 \%$ \\
\hline \multirow[t]{2}{*}{ Other } & 3,427 & $1 \%$ & $1,368,240$ & & 408 & & 7,167 & \\
\hline & 300,358 & & $4,912,232$ & & 114,458 & & 209,278 & \\
\hline
\end{tabular}


Panel B: Contract revenue and frequency by industry

\begin{tabular}{|c|c|c|c|c|c|c|c|c|}
\hline \multirow[b]{2}{*}{ NAICS Industry } & \multicolumn{4}{|c|}{ All contracts } & \multicolumn{4}{|c|}{ Cost plus contracts } \\
\hline & $\begin{array}{c}\text { Contract } \\
\text { revenue } \\
\text { (in millions) } \\
\end{array}$ & $\%$ & $\begin{array}{c}\text { \# of } \\
\text { contracts }\end{array}$ & $\%$ & $\begin{array}{c}\text { Contract } \\
\text { revenue } \\
\text { (in millions) } \\
\end{array}$ & $\%$ & $\begin{array}{c}\text { \# of } \\
\text { contracts }\end{array}$ & $\%$ \\
\hline Professional, scientific, and technical services & 108,586 & $36 \%$ & 252,848 & $5 \%$ & 71,808 & $63 \%$ & 133,448 & $64 \%$ \\
\hline Transportation equipment manufacturing & 57,522 & $19 \%$ & 429,885 & $9 \%$ & 15,884 & $14 \%$ & 21,356 & $10 \%$ \\
\hline Computer and electronic product manufacturing & 35,906 & $12 \%$ & 234,442 & $5 \%$ & 6,858 & $6 \%$ & 8,215 & $4 \%$ \\
\hline Merchant wholesalers, nondurable goods & 17,785 & $6 \%$ & 454,306 & $9 \%$ & 10 & $0 \%$ & 57 & $0 \%$ \\
\hline Administrative and support services & 10,272 & $3 \%$ & 32,511 & $1 \%$ & 5,680 & $5 \%$ & 5,402 & $3 \%$ \\
\hline Merchant wholesalers, durable goods & 7,246 & $2 \%$ & 345,302 & $7 \%$ & 54 & $0 \%$ & 82 & $0 \%$ \\
\hline Telecommunications & 7,202 & $2 \%$ & 64,842 & $1 \%$ & 779 & $1 \%$ & 1,099 & $1 \%$ \\
\hline Fabricated metal product manufacturing & 6,588 & $2 \%$ & 133,014 & $3 \%$ & 575 & $1 \%$ & 691 & $0 \%$ \\
\hline Machinery manufacturing & 6,353 & $2 \%$ & 87,216 & $2 \%$ & 744 & $1 \%$ & 1,229 & $1 \%$ \\
\hline Air transportation & 5,119 & $2 \%$ & 8,566 & $0 \%$ & 1 & $0 \%$ & 29 & $0 \%$ \\
\hline Chemical manufacturing & 4,036 & $1 \%$ & 120,157 & $2 \%$ & 96 & $0 \%$ & 79 & $0 \%$ \\
\hline Miscellaneous manufacturing & 3,859 & $1 \%$ & 167,507 & $3 \%$ & 61 & $0 \%$ & 155 & $0 \%$ \\
\hline Repair and maintenance & 3,825 & $1 \%$ & 25,850 & $1 \%$ & 1,790 & $2 \%$ & 2,483 & $1 \%$ \\
\hline Electronics and appliance stores & 3,205 & $1 \%$ & 44,088 & $1 \%$ & 130 & $0 \%$ & 201 & $0 \%$ \\
\hline Food manufacturing & 2,897 & $1 \%$ & 10,249 & $0 \%$ & 2 & $0 \%$ & 4 & $0 \%$ \\
\hline Waste management and remediation service & 2,770 & $1 \%$ & 15,920 & $0 \%$ & 1,308 & $1 \%$ & 1,758 & $1 \%$ \\
\hline Educational services & 2,765 & $1 \%$ & 14,246 & $0 \%$ & 645 & $1 \%$ & 576 & $0 \%$ \\
\hline Utilities & 2,569 & $1 \%$ & 10,032 & $0 \%$ & 32 & $0 \%$ & 113 & $0 \%$ \\
\hline Electrical equipment, appliance, and component manufact. & 2,129 & $1 \%$ & 29,662 & $1 \%$ & 165 & $0 \%$ & 260 & $0 \%$ \\
\hline Furniture and related product manufacturing & 2,101 & $1 \%$ & 46,645 & $1 \%$ & 6 & $0 \%$ & 140 & $0 \%$ \\
\hline \multirow[t]{2}{*}{ Other } & 7,624 & $3 \%$ & $2,384,944$ & & 7,831 & & 31,901 & \\
\hline & 300,358 & & $4,912,232$ & & 114,458 & & 209,278 & \\
\hline
\end{tabular}


Table 3

Descriptive statistics by contract type

Panel A: Firm-years with cost plus pricing contracts for sample of firms with one cost-plus year and one fixed control only year (619 firm-years and 258 firms)

\begin{tabular}{llllll}
\hline & Mean & Median & Std. Dev. & $25 \%$ & $75 \%$ \\
\cline { 2 - 6 } Abnormal DisExp & 0.36 & 0.00 & 1.73 & -0.22 & 0.33 \\
ROA & 0.04 & 0.05 & 0.13 & 0.02 & 0.09 \\
Assets & 8.08 & 8.09 & 2.10 & 6.78 & 9.62 \\
Market-to-book & 2.94 & 2.14 & 28.19 & 1.38 & 3.87 \\
Std ROA & 0.03 & 0.02 & 0.06 & 0.01 & 0.04 \\
Sales & 7.93 & 8.02 & 1.97 & 6.78 & 9.37 \\
Procurement sales (in millions) & 65.96 & 14.49 & 174.01 & 3.32 & 47.83 \\
\%CAS & 0.05 & 0.00 & 0.16 & 0.00 & 0.00
\end{tabular}

Panel B: Firm-years with only fixed price contracts for sample of firms with one cost-plus year and one fixed price contract only year (886 firm-years and 258 firms)

\begin{tabular}{llllll}
\hline & Mean & Median & Std. Dev. & $25 \%$ & $75 \%$ \\
\cline { 2 - 6 } Abnormal DisExp & $0.18^{* *}$ & $-0.02 * *$ & 1.36 & -0.20 & 0.31 \\
ROA & $0.02 * *$ & $0.04 * * *$ & 0.14 & 0.01 & 0.08 \\
Assets & 8.13 & 8.16 & 2.20 & 6.66 & 9.82 \\
Market-to-book & 2.69 & $2.03 *$ & 9.65 & 1.33 & 3.45 \\
Std ROA & 0.04 & 0.02 & 0.06 & 0.01 & 0.03 \\
Sales & 7.93 & 8.00 & 2.05 & 6.75 & 9.47 \\
Procurement sales (in millions) & 57.08 & $6.29 *$ & 177.19 & 1.35 & 30.52 \\
\%CAS & $0.02 * * *$ & $0.00 * * *$ & 0.12 & 0.00 & 0.00 \\
\hline
\end{tabular}

The sample consists of 1,505 firm-year observations between 2005 and 2010. Panel A includes 619 firm-years (258) firms with at least one cost plus contract. Panel B includes 886 firm-years ( 258 firms) with only fixed price contracts. $* * * * * / *$ represent statistical significance at $1 \% / 5 \% / 10 \%$ levels between the means and medians of the sample in Panel A compared to the sample in Panel B. All continuous variables are winsorized at the $1 \%$ and $99 \%$ level. Abnormal DisExp is the residual from model (1). Log assets is the natural logarithm of total assets in millions. Market-to-book is the market value of equity divided by the book value. $R O A$ is earnings before extraordinary items divided by total assets. StdROA is the standard deviation of ROA during the prior three years including year t. $L o g$ sales is the natural logarithm of sales in millions. Procurement sales is procurement contract sales in millions. $\% C A S$ is the percentage of procurement revenue subject to the cost accounting standards. 


\section{Table 4}

Regression results of return on assets on whether the firm has cost plus contracts

\begin{tabular}{lcrrr}
\hline & \multirow{2}{*}{ Pred. } & & ROA $_{\mathrm{t}}$ & $\mathrm{p}$-value \\
\cline { 2 - 5 } \cline { 4 - 5 } Intercept & & & -0.030 & $(0.35)$ \\
Cost contract & + & & $\mathbf{0 . 0 0 8}$ & $\mathbf{( 0 . 0 3 )}$ \\
Lagged ROA & + & & 0.595 & $(0.00)$ \\
Std ROA & - & & -0.372 & $(0.27)$ \\
Log sales & + & & 0.008 & $(0.05)$ \\
Log procurement sales & + & & -0.001 & $(0.32)$ \\
Year and industry indicators & & & \multicolumn{2}{c}{ Yes } \\
No. of observations & \multicolumn{3}{c}{1,505} \\
$\mathrm{R}^{2}$ & \multicolumn{3}{c}{0.606} \\
\hline
\end{tabular}

The sample consists of 1,505 firm-year observations between 2005 and 2010. The regression includes year and industry (two-digit SIC) indicator variables. The standard errors are clustered by firm and year. Two-tailed $p$ values are reported in parentheses. $* * * / * * *$ represent statistical significance at $1 \% / 5 \% / 10 \%$ levels. All continuous variables are winsorized at the $1 \%$ and $99 \%$ level. ROA is earnings before extraordinary items divided by total assets. Cost contract is an indicator variable equal to 1 if the firm has at least one cost contract, and zero otherwise. StdROA is the standard deviation of ROA during the prior three years including year t. Log sales is the natural logarithm of sales. Log procurement sales is the natural logarithm of procurement contract sales. 


\section{Table 5}

Regression results of abnormal discretionary expense on whether the firm has cost plus contracts and controls

\begin{tabular}{|c|c|c|c|c|}
\hline & $\begin{array}{l}\text { Abnormal } \\
\text { DisExp }\end{array}$ & $\mathrm{p}$-value & $\begin{array}{c}\text { Abnormal } \\
\text { DisExp_Q10 }\end{array}$ & $\mathrm{p}$-value \\
\hline Intercept & 0.230 & $(0.24)$ & -2.991 & $(0.00)$ \\
\hline Cost contract & 0.128 & $(0.04)$ & 0.411 & $(0.01)$ \\
\hline Log assets & -0.029 & $(0.22)$ & -0.071 & $(0.22)$ \\
\hline Market-to-book & 0.000 & $(0.54)$ & -0.002 & $(0.38)$ \\
\hline ROA & 0.268 & $(0.06)$ & -0.123 & $(0.74)$ \\
\hline Year and industry indicators & Yes & & Yes & \\
\hline No. of observations & 1,505 & & 1,505 & \\
\hline $\mathrm{R}^{2}$ & 0.023 & & & \\
\hline Pseudo $\mathrm{R}^{2}$ & & & 0.114 & \\
\hline
\end{tabular}

The sample consists of 1,505 firm-year observations between 2005 and 2010. The regression includes year and industry (two-digit SIC) indicator variables. The standard errors are clustered by firm and year. Two-tailed $p$ values are reported in parentheses. $* * * / * * *$ represent statistical significance at $1 \% / 5 \% / 10 \%$ levels. All continuous variables are winsorized at the $1 \%$ and $99 \%$ level. Abnormal DisExp is the residual from model (1). Abnormal DisExp_Q10 is an indicator variable equal to one if the residual from model (1) is in the highest quintile, and zero otherwise. Cost contract is an indicator variable equal to 1 if the firm has at least one cost contract, and zero otherwise. Log asset is the natural logarithm of total assets in millions. Market-to-book is the market value of equity divided by the book value. $R O A$ is earnings before extraordinary items divided by total assets. The regression with Abnormal DisExp is estimated using ordinary least squares. The regression with Abnormal DisExp_10Q is estimated using a logistic regression. 


\section{Table 6}

Regression results of return on assets on whether the firm has cost plus contracts and subject to cost accounting standards

\begin{tabular}{|c|c|c|c|}
\hline & Pred. & $\mathrm{ROA}_{t}$ & p-value \\
\hline Intercept & & -0.025 & $(0.39)$ \\
\hline Cost contract & + & 0.012 & $(\mathbf{0 . 0 2})$ \\
\hline$\% \mathrm{CAS}$ & - & -0.059 & $(0.05)$ \\
\hline Cost contract $* \% \mathrm{CAS}$ & - & -0.047 & $(0.08)$ \\
\hline Lagged ROA & + & 0.579 & $(0.00)$ \\
\hline Std ROA & - & -0.373 & $(0.26)$ \\
\hline Log sales & + & 0.008 & $(0.05)$ \\
\hline Log procurement sales & + & -0.001 & $(0.42)$ \\
\hline Year and industry indicators & & \multicolumn{2}{|c|}{ Yes } \\
\hline No. of observations & & \multicolumn{2}{|c|}{1,505} \\
\hline $\mathrm{R}^{2}$ & & \multicolumn{2}{|c|}{0.613} \\
\hline
\end{tabular}

The sample consists of 1,505 firm-year observations between 2005 and 2010. The regression includes year and industry (two-digit SIC) indicator variables. The standard errors are clustered by firm and year. Two-tailed $p$ values are reported in parentheses. $* * * / * * * *$ represent statistical significance at $1 \% / 5 \% / 10 \%$ levels. All continuous variables are winsorized at the $1 \%$ and $99 \%$ level. ROA is earnings before extraordinary items divided by total assets. Cost contract is an indicator variable equal to 1 if the firm has at least one cost contract, and zero otherwise. StdROA is the standard deviation of ROA during the prior three years including year t. Log sales is the natural logarithm of sales. Log procurement sales is the natural logarithm of procurement contract sales. \%CAS is the percentage of procurement revenue subject to the cost accounting standards. 


\section{Table 7}

Sensitivity analysis for alternative control samples

Panel A: Regression results of abnormal discretionary expense on whether the firm has cost plus contracts and controls

\begin{tabular}{|c|c|c|c|c|c|}
\hline \multirow[b]{2}{*}{ Intercept } & \multirow[t]{2}{*}{ Pred. } & $\begin{array}{l}\text { Abnormal } \\
\text { DisExp }\end{array}$ & \multicolumn{2}{|r|}{$\begin{array}{l}\text { Highest } \\
\text { quintile of } \\
\text { abnormal } \\
\text { DisExp }\end{array}$} & $\mathrm{p}$-value \\
\hline & & 0.4660 & $(0.01)$ & 0.4205 & $(0.19)$ \\
\hline Cost contracts & + & 0.0659 & $(\mathbf{0 . 0 5})$ & 0.0906 & $(0.04)$ \\
\hline Log assets & + & -0.0506 & $(0.00)$ & -0.0339 & $(0.07)$ \\
\hline Market-to-book & - & 0.0004 & $(0.33)$ & 0.0001 & $(0.85)$ \\
\hline ROA & + & 0.2938 & $(0.03)$ & 0.3139 & $(0.04)$ \\
\hline \multirow{2}{*}{\multicolumn{2}{|c|}{$\begin{array}{l}\text { No. of observations } \\
\mathrm{R}^{2}\end{array}$}} & \multicolumn{2}{|c|}{5,754} & \multicolumn{2}{|c|}{2,201} \\
\hline & & \multicolumn{2}{|c|}{0.088} & \multicolumn{2}{|c|}{0.061} \\
\hline \multicolumn{6}{|c|}{$\begin{array}{l}\text { Panel B: Regression results of return on assets on whether the firm has cost plus } \\
\text { contracts and cost accounting standards clause }\end{array}$} \\
\hline & & \multicolumn{2}{|c|}{ All contractors } & \multicolumn{2}{|c|}{$\begin{array}{l}\text { All contractors with } \\
\text { at least one cost } \\
\text { contract }\end{array}$} \\
\hline & Pred. & $\mathrm{ROA}_{\mathrm{t}}$ & $\mathrm{p}$-value & $\mathrm{ROA}_{\mathrm{t}}$ & $\mathrm{p}$-value \\
\hline \multicolumn{2}{|l|}{ Intercept } & 0.1245 & $(0.20)$ & 0.0044 & $(0.82)$ \\
\hline Cost contract & + & 0.0045 & $(0.02)$ & 0.0070 & $(\mathbf{0 . 0 3})$ \\
\hline Lagged ROA & + & 0.5511 & $(0.00)$ & 0.5396 & $(0.00)$ \\
\hline Std ROA & - & -0.2087 & $(0.08)$ & -0.4501 & $(0.17)$ \\
\hline Log sales & + & 0.0093 & $(0.00)$ & 0.0061 & $(0.03)$ \\
\hline Log procurement sales & + & -0.0004 & $(0.55)$ & -0.0019 & $(0.13)$ \\
\hline \multicolumn{2}{|c|}{ Year and industry indicators } & \multicolumn{2}{|c|}{ Yes } & \multicolumn{2}{|c|}{ Yes } \\
\hline \multicolumn{2}{|c|}{ No. of observations } & \multicolumn{2}{|c|}{5,754} & \multicolumn{2}{|c|}{2,201} \\
\hline \multicolumn{2}{|l|}{ No. of firms } & \multicolumn{2}{|c|}{1,137} & \multicolumn{2}{|c|}{383} \\
\hline \multicolumn{2}{|l|}{$\mathrm{R}^{2}$} & \multicolumn{2}{|c|}{0.44} & \multicolumn{2}{|c|}{0.57} \\
\hline
\end{tabular}


The sample consists of 1,505 firm-year observations between 2005 and 2010. The regressions include year and industry (two-digit SIC) indicator variables. The standard errors are clustered by firm and year. Two-tailed $p$ values are reported in parentheses. $* * * / * * *$ represent statistical significance at $1 \% / 5 \% / 10 \%$ levels. All continuous variables are winsorized at the $1 \%$ and $99 \%$ level. Abnormal DisExp is the residual from model (1). Abnormal DisExp_Q10 is an indicator variable equal to one if the residual from model (1) is in the highest quintile, and zero otherwise. Cost contract is an indicator variable equal to 1 if the firm has at least one cost contract, and zero otherwise. Log asset is the natural logarithm of total assets in millions. Market-to-book is the market value of equity divided by the book value. $R O A$ is earnings before extraordinary items divided by total assets. Cost contract is an indicator variable equal to 1 if the firm has at least one cost contract, and zero otherwise. StdROA is the standard deviation of ROA during the prior three years including year t. Log sales is the natural logarithm of sales. $\log$ 